\title{
Survival of side grafts with scions from pure species Pinus engelmannii Carr. and the $P$. engelmannii $x$ P. arizonica Engelm. var. arizonica hybrid
}

\author{
Alberto Pérez-Luna ${ }^{1}$, Christian A Wehenkel ${ }^{2}$, José A Prieto-Ruíz ${ }^{3}$, Javier López-Upton ${ }^{4}$, José C Hernández-Díaz \\ Corresp. 2 \\ 1 Programa Institucional de Doctorado en Ciencias Agropecuarias y Forestales, Universidad Juárez del Estado de Durango, Durango, Mexico \\ 2 Instituto de Silvicultura e Industria de la Madera, Universidad Juárez del Estado de Durango, Durango, Mexico \\ 3 Facultad de Ciencias Forestales, Universidad Juárez del Estado de Durango, Durango, Mexico \\ ${ }^{4}$ Campus Montecillo, Colegio de Posgraduados, Texcoco, Estado de México, Mexico \\ Corresponding Author: José C Hernández-Díaz \\ Email address: jciroh@ujed.mx
}

Grafting is one of the most widely used methods for vegetative propagation, particularly for multiplying trees considered important, but there has been little research done on the effect of hybridization on grafts from the genus Pinus. Sometimes hybrids show the ability to reproduce and adapt efficiently to the environment. However, they reduce the genetic gain of seed orchards. The objective in this research was to evaluate the effect of scion grafts from pure species donor Pinus engelmannii Carr. and from putative hybrid trees $P$. engelmannii. x P. arizonica Engelm., grafted on rootstocks of pure species Pinus engelmannii, along with the effect of the position of the scion in the donor tree crown (upper third and middle third). The scions were collected from three pure species trees and three hybrids. In each tree, 20 scions were collected from each third of the crown evaluated. 120 side-veneer grafts were made at the beginning of spring (March) 2018. Variance analyses were performed to evaluate the treatments and adjustments of the Logit and Weibull models to obtain the probability of graft survival. Significant differences were found between the origins of scions ( $p \leq 0.0083$, after Bonferroni correction), showing grafts with hybrid tree scions taking hold better. In addition, the probability of survival at five months after grafting with hybrid tree scions was greater $(p \leq 0.0001)$ than in grafts with pure-species tree scions (Logit model), which coincides with the results of the Weibull model, which indicated that the probability of graft death with pure species donor tree scions is greater than for grafts with hybrid scions. There were no significant differences regarding the position of the scion in the donor tree crown. 


\section{Survival of side grafts with scions from pure species Pinus}

\section{2 engelmannii Carr. and the $P$. engelmannii $x$ P. arizonica}

3 Engelm. var. arizonica hybrid

Alberto Pérez-Luna ${ }^{1}$, Christian Wehenkel ${ }^{2}$, José Ángel Prieto-Ruíz ${ }^{3}$, Javier López-Upton ${ }^{4}$, José

6 Ciro Hernández-Díaz ${ }^{2}$

7

8

${ }^{1}$ Programa Institucional de Doctorado en Ciencias Agropecuarias y Forestales, Universidad Juárez del Estado de Durango, Constitución 404 sur Zona Centro, CP 34000 Durango, México ${ }^{2}$ Instituto de Silvicultura e Industria de la Madera, Universidad Juárez del Estado de Durango, Boulevard del Guadiana 501, Ciudad Universitaria, Torre de Investigación, CP 34120, Durango, México

${ }^{3}$ Facultad de Ciencias Forestales, Universidad Juárez del Estado de Durango, Río Papaloapan y Blvd. Durango S/N Col. Valle del Sur, CP 34120, Durango, México

${ }^{4}$ Colegio de Postgraduados, Campus Montecillo, Carretera México-Texcoco Km 36.5, CP 56230, Montecillo, Texcoco, Estado de México, México

Corresponding Author:

José Ciro Hernández Díaz ${ }^{1}$

Email address: jciroh@ujed.mx

\section{Abstract}

Grafting is one of the most widely used methods for vegetative propagation, particularly for multiplying trees considered important, but there has been little research done on the effect of hybridization on grafts from the genus Pinus. Sometimes hybrids show the ability to reproduce and adapt efficiently to the environment. However, they reduce the genetic gain of seed orchards. The objective in this research was to evaluate the effect of scion grafts from pure species donor Pinus engelmannii Carr. and from putative hybrid trees P. engelmannii. x P. arizonica Engelm., grafted on rootstocks of pure species Pinus engelmannii, along with the effect of the position of the scion in the donor tree crown (upper third and middle third). The scions were collected from three pure species trees and three hybrids. In each tree, 20 scions were collected from each third of the crown evaluated. 120 side-veneer grafts were made at the beginning of spring (March) 2018. Variance analyses were performed to evaluate the treatments and adjustments of the Logit and Weibull models to obtain the probability of graft survival. Significant differences were found between the origins of scions ( $p \leq 0.0083$, after Bonferroni correction), showing grafts with hybrid tree scions taking hold better. In addition, the probability of survival at five months after grafting with hybrid tree scions was greater $(p \leq 0.0001)$ than in grafts with pure-species tree scions (Logit model), which coincides with the results of the Weibull model, which indicated 
40 that the probability of graft death with pure species donor tree scions is greater than for grafts

41 with hybrid scions. There were no significant differences regarding the position of the scion in

42 the donor tree crown.

43

Key Words Vegetative propagation, Hybridization, Position in the crown, Logit Model, Weibull Model

46

47

48

49

50

51

52

53

54

55

56

57

58

59

60

61

62

63

64

65

66

67

68

69

70

71

72

73

74

75

76

77

78

79

\section{Introduction}

Between 1990 and 2010, Mexico was one of seven countries with the highest annual net loss of forest area, with an approximate deforestation rate of 500,000 ha per year (FAO-CONAFOR, 2009; Rosete-Vergés et al., 2014). In Durango, Mexico, from 1986 to 2012, 886,679 hectares of forest cover were lost due to different types of disturbances, which represented $17.73 \%$ of the total forest area in the State (Novo-Fernández et al., 2018). This growing degradation of Mexican forests, caused by the loss of forest cover, contributes to the annual deficit of approximately 30 million cubic meters of wood, which is due to the increase in national consumption of this raw material and the $20 \%$ increase in demand for forest products in North America (Fiedler et al. 2001; Chidumayo \& Gumbo, 2013; SEMARNAT, 2016). It is necessary to promote genetic improvement programs that allow the safeguarding, propagation and improvement of genotypes of high ecological, commercial and cultural value (Neale \& Kremer, 2011; Wheeler et al., 2015; Gray et al., 2016). Likewise, genetic improvements may allow for the obtaining of better survival and productivity results in commercial forest plantations, which in Mexico have an approximate annual mortality rate of 45\% (Muñoz-Flores et al., 2012; Rosales-Mata et al., 2015).

In northern Mexico and the southern United States of America, P. engelmannii and P. arizonica Engelm var. arizonica are two of the most important conifers from an ecological and commercial standpoint (Barton, Swetnam \& Baisan, 2001; García-Arévalo \& González-Elizondo, 2003; Ávila-Flores et al., 2016a; Friedrich et al., 2018). In addition, P. engelmannii is one of the most utilized species in northern Mexico in commercial forest plantations, since this species' wood has a high demand and economic value (Prieto-Ruiz et al., 2004). P. engelmannii trees can reach up to $35 \mathrm{~m}$ in height and up to $100 \mathrm{~cm}$ in diameter (Ávila-Flores et al., 2016a; Avila-Flores et al., 2016b). P. arizonica trees can reach up to $25 \mathrm{~m}$ in height and $80 \mathrm{~cm}$ in diameter, with a straight trunk and a natural self-pruning that helps reduce mechanical and aesthetic defects in the wood (Barton, Swetnam \& Baisan, 2001; García-Arévalo \& González-Elizondo, 2003). P. engelmannii needles present 6 to 23 stomata rows on the dorsal side and 5 to 9 rows on the ventral side; while $P$. arizonica needles have 3 to 8 rows on the dorsal side and 3 to 7 rows on the ventral side (García-Arévalo \& González-Elizondo, 2003). Yeaton, Yeaton \& Waggoner III (1983) described that pine species trees from Durango, Mexico, that have fewer stomata rows on the dorsal and ventral sides of the needles, are more stress-tolerant and have a tendency to grow in semi-arid environments.

The genetic improvement of forest species is mainly carried out in asexual seed orchards (ASO) and in clone banks (CB). In ASO, genetically enhanced seed is produced through open or 
80

81

82

83

84

85

86

87

88

89

90

91

92

93

94

95

96

97

98

99

100

101

102

103

104

105

106

107

108

109

110

111

112

113

114

115

116

117

118

119

controlled pollination (Stewart et al. 2016) and in CB, it is possible to produce identical clones through vegetative propagation (Mutke, Gordo \& Gil, 2005; Şevik \& Topaçoğlu, 2015; Oliveira, Nogueira \& Higa, 2018). Grafting is the most widely used method of vegetative propagation to establish ASO and CB in the genus Pinus (Jayawickrama, Jett \& McKeand, 1991; Stewart et al., 2016; Vargas-Hernández \& Vargas-Abonce, 2016; Pérez-Luna et al., 2019).

A graft is the union of a rootstock and a scion of different origin, which form a new combination of cells that gives rise to a new plant (Mudge et al., 2009). Grafts can be intraspecific (scion and rootstock of the same species) or interspecific (scion and rootstock of different species) (Opoku, Opuni-Frimpong \& Dompreh, 2018), and both types have been used in coniferous grafting (Lott et al., 2003; Barnes, 2008). The most commonly used grafting techniques in Pinus species are top cleft and side-veneer (Staubach \& Fins, 1988; Cuevas-Cruz, 2014; Pérez-Luna et al., 2019). Although in many cases coniferous grafting has been successfully achieved (Hibbert-Frey et al., 2011; Almqvist, 2013a), in Pinus engelmannii Carr., the survival rate has been low (Pérez-Luna et al., 2019).

The following are the main factors involved in the success rate of coniferous and other vegetal species grafting: The technique used in grafting, the skill level of the person doing the grafting, rootstock quality, scion's vigor, origin of scions and rootstocks (Jayawickrama, Jett \& McKeand, 1991; Lott et al., 2003), position of the scions in the crown of donor trees, the age of scion donor trees, genetic, taxonomic and anatomical characteristics (Lott et al., 2003; Hibbert-Frey et al., 2011; Pérez-Luna et al., 2019), cell compatibility of the scion with the rootstock, the correct connection of cell tissue and the presence or absence of growth regulators hormones (gibberellins, auxins and cytokinins, for example) (Valdés, Centeno \& Fernández, 2003; Pina \& Errea, 2005).

Another factor that can influence the success of grafting is the amount of resin channels in parent species. P. engelmannii has more resin channels than P. arizonica (García-Arévalo \& GonzálezElizondo, 2003), and Pérez-Luna et al. (2019) found that a larger the amount of resin channels in the scion lead to a smaller percentage of graft compatibility.

Elongation of grafts can be observed in the first or second month after grafting (Pérez-Luna et al., 2019). Flowering can occur on the grafts two years after grafting has taken place. However, the seed production time of grafts in Pinus species can vary from five to seven years, depending on the species (Luukkanen \& Johansson, 1980; Pijut, 2002). One method that is used to accelerate seed production in grafts is the application of hormones, such as gibberellins (Hare, 1984; Pijut, 2002).

Although grafts may sometimes show adequate initial growth and flowering (Pérez-Luna et al., 2019), mortality can occur due to possible incompatibility between the scion and the rootstock after germplasm production, even five years or more after grafting (Jayawickrama, Jett \& McKeand, 1991; Valera et al., 1999; Valdés, Centeno \& Fernández, 2003). The origin of this incompatibility can be genetic and/or anatomical (Lott et al., 2003; Pérez-Luna et al., 2019). Using hybrids can be an alternative to improve commercial plantations and restore degraded forest ecosystems (Lopez et al., 2018; Skousen et al., 2018). Natural hybridization between Pinus 
120

121

122

123

124

125

126

127

128

129

130

131

132

133

134

135

136

137

138

139

140

141

142

143

144

145

146

147

148

149

150

151

152

153

154

155

156

157

158

159

species can be detected through morphological analysis (Garcia-Arévalo \& González-Elizondo, 2003), but it is better to apply molecular markers techniques, such as AFLP (Ávila-Flores et al., 2016a). In certain regions of the state of Durango, putative hybrids have been observed as a product of natural cross between Pinus species, such as $P$. engelmannii x $P$. arizonica, which have adapted to sites with adverse climatic conditions (Ávila-Flores et al., 2016a).

In grafting, the use of hybrids has been studied in conifer species (Marchal et al., 2017; Kita et al., 2018), however, in pines, it has not been studied much (Lott et al., 2003). In contrast, some plants, such as tomato and watermelon have been studied extensively, and survival levels greater than 80\% have been reported (Djidonou et al., 2016; Xu et al., 2016; Zhang et al., 2019). Survival models are very useful to make predictions about the probability of survival and death through the time, as a function of two or more treatments (Kleinbaum \& Klein, 2002; Zhang, 2016). The development of models, such as the Cox proportional hazards model, Weibull accelerated failure time model, Weibull risk function, as well as the Logit model, have had great application in clinical analyzes (Sullivan, Massaro \& D'Agostino, 2004; Vazquez et al., 2009; Chaou et al., 2017). However, they have been scarcely used in forestry research (Pérez-Luna et al., 2019).

The objective of this study was to determine the survival in Pinus engelmannii grafting by using scions, both from pure species donor trees and putative hybrids identified with AFLP, as well as the influence of the position of the scion in the donor tree crown (upper third and middle third). The rootstocks were produced using seeds from a stand that was identified as pure species $P$. engelmannii, on the basis of its morphological characteristics. The possible effect of six graft variables of the scions and rootstocks on the probability of survival, at five months after grafting, was also evaluated. In this study, we successfully applied several of the models mentioned above, which can also be useful in enriching statistical analysis in future forestry research.

\section{Materials \& Methods}

\section{Place of origin and preparation method of rootstocks}

The seed to produce the rootstocks was collected in a natural stand of Pinus engelmannii trees located in Empalme Purísima, municipality of Durango, Dgo., Mexico, at coordinates $23^{\circ} 55^{\prime}$ $48.1^{\prime \prime} \mathrm{N}$ and $105^{\circ} 05^{\prime} 43.0^{\prime \prime} \mathrm{W}$, at 2,480 $\mathrm{m}$ altitude. In this stand, no morphological evidence of natural hybridization was observed, for which reason the rootstocks produced were considered pure species trees of said specie. For 11 months the rootstocks grew in 77-cavity, expanded polystyrene seedling trays with $170 \mathrm{~mL}$ per cavity $^{-1}$. Afterwards, the plant grew for 19 months in black polyethylene $5 \mathrm{~L}$ bags $(20 \mathrm{~cm}$ in width and $30 \mathrm{~cm}$ in length). At the time of grafting, the rootstocks were 2.5 years old. During this period, the plants reached an average neck diameter of $18.4 \mathrm{~mm}$ and an average height of $17.4 \mathrm{~cm}$.

\section{Selection of donor trees and collection of scions}

The scions were collected in a free access natural stand located in the area known as El Río, in the Ejido La Casita, municipality of Durango, Dgo., Mexico, at coordinates $23^{\circ} 43^{\prime} 26.8^{\prime}$ ' N and $104^{\circ} 47^{\prime} 27.1^{\prime \prime} \mathrm{W}$, at an altitude of $2,335 \mathrm{~m}$. A permit for the collection of samples in the field was not required, since the species studied are not under any conservation status. The scions 
160

161

162

163

164

165

166

167

168

169

170

171

172

173

174

175

176

177

178

179

180

181

182

183

184

185

186

187

188

189

190

191

192

193

194

195

196

197

198

199

were collected on March 15, 2018, from a seed producer stand consisting of both tree types, pure species $P$. engelmannii and $P$. engelmannii x $P$. arizonica hybrids, detected by AFLP and morphological traits (analyzed by Ávila-Flores et al., 2016a).

Scions' donor trees were divided in the two categories of hybrids and pure species trees, based on the membership probabilities (MP) of each individual to pure Pinus engelmannii (pure trees corresponded to an MP larger than 0.945, while the hybrids' MP was smaller than 0.610). Three trees were chosen from each category; the growth and vigor of each was similar between these two categories within the stand (Ávila-Flores et al., 2016a).

The average age of the three pure species trees was 37 years, with a height of $13 \mathrm{~m}$ and diameter of $30 \mathrm{~cm}$ on average. The age of the hybrid trees also was 37 years, with a height of $14.5 \mathrm{~m}$ and a diameter of $36 \mathrm{~cm}$ on average. During the collection of the donor trees scions, selected from the pure species of Pinus engelmannii and P. engelmannii x P. arizonica hybrids, the following morphological differences were detected between the studied groups of trees: Conical crown in the pure species trees and irregular shaped crown in the hybrids trees, slightly hanging branches in the lower part of the hybrid tree crowns, while more erect branches in the whole crown of the pure species trees (Fig. 1A and Fig. 1B). The cone size of the $P$. engelmannii x $P$. arizonica hybrids was smaller than the cones of the pure species $P$. engelmannii (Fig. 1C and Fig 1D). Erect fascicles in the pure species trees and fallen fascicles in hybrids (Fig. 1E and Fig. 1F). From the crown of each donor tree, 20 scions were collected from the upper third and 20 from the middle third. Each scion had an approximate length of $20 \mathrm{~cm}$. In order to safely transport the scions to the grafting site, they were packed in rectangular $72 \mathrm{~L}$ plastic boxes containing sawdust moistened with a solution of Captán ${ }^{\circledR}$ fungicide at a dose of 3 gL-1, to prevent the drying of the scions and their contamination by fungi. Of the 20 scions collected from each tree, only 10 were selected to be grafted. The selection of these scions was made according to their possibility of diameter size tie with the rootstocks.

\section{Grafting}

The grafting was done in the nursery at the Instituto de Silvicultura e Industria de la Madera de la Universidad Juárez del Estado de Durango (ISIMA-UJED). The grafts were placed in a 6 x 8 x 3 meter greenhouse with a white plastic cover. To reduce the temperature inside the greenhouse, two shade meshes were placed above the roof, with an average spacing of $30 \mathrm{~cm}$ between them. The upper mesh had 70\% light retention and the lower mesh had 50\% light retention. 120 grafts were made using Pinus engelmannii rootstocks; 60 of these grafts were done with scions from $P$. engelmannii x $P$. arizonica hybrid donor trees, and the other 60 with scions from pure species of $P$. engelmannii trees. The grafting was done on March 16, 2018, one day after the scions were picked. The side-veneer grafting technique described by Muñoz-Flores et al. (2013) and Pérez-Luna et al. (2019) was used.

The graft substrate was watered every three days and as a complement in each irrigation, triple 19 water-soluble fertilizer (N-P-K) was applied at a dose of $3 \mathrm{gL}^{-1}$. Fertigation was carried out during the five months of evaluation, using a $7 \mathrm{~L}$ manual watering can. In addition, from the second month after grafting (May 2019) Promyl ${ }^{\circledR}$ fungicide was applied to plants's substrates 
200 through irrigation at a dose of $2 \mathrm{gL}^{-1}$ to prevent fungal damage. This activity was carried out 201 every eight days for a month.

\section{Treatments, variables evaluated and statistical analysis}

203 Four treatments were evaluated: Two types of donor trees (Pinus engelmannii x P. arizonica 204 hybrids and pure species $P$. engelmannii) and two positions of the scions in the donor tree crown 205 (middle and upper third). Each graft represented an experimental unit, and there were 30 206 repetitions for each treatment, distributed under a randomized block arrangement.

207 Before grafting, the following graft variables corresponding to the scions and rootstocks were 208 recorded: Scion length (SL), scion diameter (SD), rootstock height $(\mathrm{RH})$, rootstock diameter at 209 the root crown (RD), graft height $(\mathrm{GH})$ and rootstock diameter at graft height (GD). The sections 210 of scions and rootstocks measured for obtaining the grafts variables are described in Figure 2. 211 An analysis of variance (one-way ANOVA) was performed in the R program (R Core Team, 212 2013), finding significant differences between the pure species and hybrid donor trees in regard 213 to the values of each analyzed graft variable (Table 1).

214 After grafting, graft survival was evaluated as a response variable each month for five months. 215 As independent variables, the type of scion donor tree (hybrid or pure species tree) (TDT), the 216 position of the scion in the donor tree crown (SPC) and the graft variables obtained from the 217 scions and rootstocks were considered. The normality of the graft variables was evaluated with 218 the Kolmogorov-Smirnov test. To evaluate the effect of the treatments on survival, an analysis of 219 variance and a comparison test of means, with a proposed initial value of alpha $=0.05$, were 220 performed with the data obtained in each month.

221 Before carrying out this test and in order to reduce the probability of committing a type I error, 222 the Bonferroni correction was applied to adjust the level of significance (Weisstein, 2004), 223 resulting in the corrected alpha value $=0.0083$, which was obtained by dividing the initial value 224 of alpha by the number of parallel comparisons $(0.05 / 6=0.0083)$. The same adjustment and 225 corrected alpha value (0.0083) was used in the analysis of all the survival models described 226 below.

227 Also, a Pearson's correlation test was performed to detect the possible multicollinearity between 228 the analyzed graft variables, and thus be able to discriminate the redundant variables in the 229 adjustment of the evaluated survival models. In addition, two models were adjusted to determine 230 the probability of graft survival based on the treatments evaluated. These models were the Logit 231 function and the Weibull accelerated failure time model. All the statistical tests described were 232 performed on the free software platform $\mathrm{R}$ (R Core Team, 2013).

\section{Adjustment in the Logit model}

234 To assess the effect of treatments and graft variables on the probability of occurrence of 235 successful events (graft survival) at the end of the evaluation period, the non-parametric Logit 236 model (Hastie \& Tibshirani, 1987; Kleinbaum \& Klein, 2002), was adjusted with the "aod" 237 package of the R platform (R Core Team, 2013). The Logit model is defined by the following 238 equation: 


$$
p\left(x_{i}\right)=\frac{1}{1+e^{-\left(\alpha+\sum \beta_{i} x_{i}\right)}}
$$

239 Where: $\mathrm{p}\left(x_{i}\right)$ is the probability of occurrence of an event to be evaluated (in this case the survival 240 of grafts) of the response variable, which is inversely proportional to an exponential function 241 elevated to the sum of the intercept $\alpha$ and $n$ predictors $x$. The Logit model works with 242 dichotomous (dummy) and discrete variables. Likewise, the adjustment of the Logit model 243 generates estimators of the $\beta$ coefficients for the predictors; if the value of the estimator is 244 positive, the probability of occurrence of the successful event $\left(p\left(x_{i}\right)\right)$ increases when the value of 245 the respective independent variable $\left(x_{i}\right)$ increases by one unit, and if the estimator is negative, the 246 probability of the successful event decreases by increasing the value of the independent variable 247 by one unit (Kleinbaum \& Klein, 2002).

248 Furthermore, the Logit model generates the odds ratio that allows determining the probability of 249 occurrence of the event to be evaluated (survival rate) (Bland \& Altman, 2000; Kleinbaum \& 250 Klein, 2002; Aedo, Pavlov \& Clavero, 2010). The equation to calculate the odds ratio is:

$$
\text { Odds ratio }=\frac{p\left(x_{1}\right)\left(1-p\left(x_{0}\right)\right)}{p\left(x_{0}\right)\left(1-p\left(x_{1}\right)\right)}
$$

251

252

253

254

255

256

257

258

259

260

261

262

263

264

265

266

267

Where $p\left(x_{1}\right)$ is the probability of the occurrence of the graft survival event with hybrid donor tree scions and $p\left(x_{0}\right)$ is the probability of graft survival with pure species donor tree scions. The interpretation of the odds ratio is always relative, since its value is dimensionless and is obtained by dividing the product of multiplying the probability of graft survival with hybrid tree scions $\left(p\left(\mathrm{x}_{1}\right)\right)$ by the probability of graft mortality with pure species tree scions $\left(1-p\left(\mathrm{x}_{0}\right)\right)$, divided by the product of multiplying the probability of graft survival with pure species tree scions $\left(p\left(x_{0}\right)\right.$ by the probability of graft mortality with hybrid tree scions (1- $p\left(x_{1}\right)$ ) (Bland \& Altman, 2000;

Kleinbaum \& Klein, 2002; Aedo, Pavlov \& Clavero, 2010).

To calculate the odds ratio, the most successful treatment of the event to be evaluated is used as a reference; that is, if the odds ratio of survival is desired to be obtained, the first factor of the numerator (Eq. 2), will be the $p\left(x_{i}\right)$ of the treatment with the highest proportion of living specimens, which in this study was the graft of hybrid tree scions $\left(x_{1}=1\right)$, that is to say $p\left(x_{1}\right)$ and therefore the first denominator factor will be $p\left(x_{0}\right)$, which is the proportion of live grafts coming from the other treatment (pure species tree scions).

However, the odds ratio can also be calculated in another way, through an operation that involves the relative frequencies of the living and dead specimens of each treatment under study (Eq. 3) (Kleinbaum \& Klein, 2002).

$$
\text { Odds ratio }=\frac{a \times d}{b \times c}
$$


269 Where: $a$ is the relative frequency of hybrid tree scion grafts $\left(x_{1}=1\right)$ that are alive at the end of 270 the evaluation period and $c$ is the relative frequency of pure-species tree scion grafts $\left(x_{0}=0\right)$ that 271 are found alive at the end of that period, while $b$ and $d$ are the relative frequencies of dead grafts 272 of hybrid tree scions $\left(x_{1}=1\right)$ and pure species tree scions $\left(x_{0}=0\right)$, respectively.

273 In the study, graft survival was considered as the event to be evaluated. To evaluate it, dead 274 grafts were coded with zero (0), while live grafts were coded as one (1), in order to obtain the 275 odds ratio of the most successful treatment (survival) and contrast it with the treatment of least 276 survival. In the case of the variables referring to the type of scion donor tree and the scion

277

278

279

280

281

282

283

284

285

286

287

288

289

290

291

292

293

294

295

296

297

298

299

300

301

302

303

304

305

306

307 position in the donor tree crown, the following dichotomous coding was used: grafts with pure species tree scions (0) and grafts with hybrid tree scions (1); grafts with scions from the upper third of the crown (0) and grafts with scions from the middle third of the crown (1).

\section{Adjustment of the Weibull accelerated failure time model and the Weibull risk function}

Graft survival was analyzed with a Weibull accelerated failure time model (AFT) under a twoparameter Weibull distribution to obtain the graft mortality risk ratio (hazard ratio) based on the evaluated treatments and variables. The AFT model was adjusted with the R "survival" library (R Core Team, 2013). For this, the variables TDT (type of donor tree), SPC (scion position in the crown) and the graft variables were used as predictor variables. The AFT model is a logarithmiclinear variant of the Weibull distribution model (van Houwelingen, 2000), and allows estimating the effect of a variable or set of variables on the duration of survival, which helps to estimate the average time $(T)$ in which there is at least one failure (illness or death) (Carroll, 2003; Zhang, 2016). This model is defined as:

$$
\operatorname{In}(T)=\alpha+\delta x+\sigma \varepsilon
$$

Where: $\operatorname{In}(T)$ is the natural logarithm of the average time $(T)$ in which it is estimated that there will be at least one mortality (failure) event among the evaluated variables (live grafts), $\alpha$ is the scale parameter, $\delta$ it is the coefficient of the explanatory variable, which in the AFT model is known as the "acceleration factor", $\sigma$ is the shape parameter of the model and $\varepsilon$ is the error of the distribution function (George, Seals \& Aban, 2014). All these parameters were estimated with the "survival" library of the R program (R Core Team, 2013). In the AFT model, if $\delta<0$ the survival time decreases due to the effect of the variable $x$, if $\delta=0$ the effect of $x$ is constant, so the survival time does not increase or decrease due to the effect of any change in the value of the variable $x$, and if $\delta>0$ the survival time increases due to the effect of the variable $x$. To interpret the value of $\delta$ linearly, it is necessary to apply this coefficient as an exponent, that is, $e^{(\delta)}(Q i$, 2009). It is important to mention that if $\delta<0$ the value of $\alpha$ increases, and if $\delta>0$ the value of $\alpha$ decreases, keeping the value of $\sigma$ constant in both cases. Therefore, the effect of the predictor variable $x$ is multiplicative (logarithmic) on the time scale, so it is said that this model accelerates (increases or decreases) the estimated average survival time of the specimens studied up to time $T$, which depends on the effectiveness or ineffectiveness of the treatments evaluated. Said time $T$ is always longer than the duration of the evaluation (Carroll, 2003; Ghorbani et al., 2016; Zhang, 2016). On the other hand, it is also necessary to apply the exponent "time" $T\left(e^{(T)}\right)$ to obtain a linear result of the estimated survival time after the graft evaluation period. 
308

309

310

311

312

313

314

315

316

317

318

In addition, this study allowed adjusting the Weibull risk function to estimate the probability of occurrence of negative events (graft mortality). To make this adjustment, the "SurvRegCensCov" library was used, which allows transforming the AFT model into the Weibull risk function, which is defined as:

$$
h(t)=\lambda \gamma\left(t e^{-\beta x}\right)^{\lambda-1} e^{-\beta x}
$$

Where: $h(\mathrm{t})$ is the risk function, $\lambda$ is the model form parameter $(\lambda>0), \gamma$ is the scale parameter $(\gamma>$ $0), \beta$ is the explanatory variable coefficient, which can take values between positive and negative infinity (Carroll, 2003). Finally, $t$ is the average elapsed survival time in which graft mortality events occurred at some moment within the evaluation period (note that $t<T$ ), when the start of the first monthly evaluation is considered as the study origin. The values for the parameters $\lambda, \gamma$ and $\beta$ are estimated with the following equations, that imply the use of the parameters calculated for the above AFT model (Eq. 4):

$$
\begin{gathered}
\lambda=e^{-\alpha / \sigma} \\
\gamma=\frac{1}{\sigma} \\
\beta=\frac{-\delta}{\sigma}
\end{gathered}
$$

319

320

321

322

323

324

325

326

327

328

329

330

331

332

333

334

335

336

337

338

In turn, the Weibull risk function allows obtaining the risk coefficient or ratio (hazard ratio, HR) of an explanatory variable $(x)$, which measures a specimen's probability of death based on said variable, over a time $(t)$ previously defined by the researcher. If $\lambda>1$ the value of HR increases, while HR decreases if $\lambda<1$ (Carroll, 2003; Zhang, 2016). If the value of the hazard ratio is 1.0, means that the risk of death is equal between treatments; if the value of the hazard ratio is less than one, it means a reduction in the risk of death in one of the treatments, while if the hazard ratio is greater than one, the risk of death increases in one of the treatments (Carroll, 2003; Ghorbani et al., 2016) The HR is determined by the following equation (Igl, 2018):

$$
H R=\left(e^{-\beta}\right)^{\lambda-1}
$$

The parameters $\beta$ and $\lambda$ of the HR equation (Eq. 9), are the same parameters calculated for the Weibull risk function (Eq. 5).

The Weibull risk function model uses dummy variables to predict the HR. To perform survival analysis on the R platform, the "censored" data is used to indicate living specimens, which are coded with a zero (0) (Pohar \& Stare, 2006). The censored data are those specimens which are alive at the end of the evaluation, and are named that way because it is not possible to know precisely at what time they will experience the death event. Therefore, dead grafts at the end of the evaluation period were coded with a one (1). The donor-tree type (TDT) and scion position in the donor's tree crown (SPC) were coded as follows: Grafts made with pure-species tree scions (0) and grafts made with hybrid tree scions (1); grafts with scions from the upper third of the crown (0) and grafts with scions from the middle third of the crown (1).

\section{Results}




\section{Survival Rate}

340 Figure 3 shows the results of grafts survival during the first four months of evaluation. In the first

341 month after grafting, the survival condition of the scion grafts from the middle third of the crown

342 of hybrid trees was total, while the treatment with lower survival was that of scion grafts from

343 the upper third of the crown of pure species trees with $86.6 \%$.

344 On the other hand, scion graft treatments from the middle third of the pure species tree crown

345 and scion grafts from the upper third of the hybrid tree crown had $90.0 \%$ and $93.3 \%$ survival,

346 respectively. In the first monthly evaluation no significant differences were found between

347 treatments $(p=0.390)$.

348 In the second month of evaluation, scion treatments from the upper third of the pure-species tree

349

350

351

352

353

354

355

356

357

358

359

360

361

362

363

364

365

366

367

368

369

370

371

372

373

374

375

376

377

378 crown and scions from the middle third of the pure-species tree crown, showed a survival of less than $80 \%$. In contrast, scion grafts from the middle third of the crown of hybrid trees survived in their entirety, while the survival in the treatment of scion grafts from the upper third of the crown of hybrid trees was 93.3\%; even so, no significant differences were found $(p=0.126)$.

In the third month of evaluation, survival decreased to $66.6 \%$ for both scion treatments of pure species-donor trees; the treatment with the highest survival was that of grafts made with scions from the upper third of the crown of hybrid trees with $93.3 \%$. The survival of the scion grafts from the middle third of the crown of hybrid trees decreased from $100 \%$ to $86.6 \%$ in the third month of evaluation; however, the four treatments were statistically equal $(p=0.128)$.

Survival decreased in the four treatments in the fourth month of evaluation, when the best treatment was that of scion grafts from the upper third of the crown of hybrid trees, with survival at $86.6 \%$, however, the treatments continued without showing significant differences $(p=$ $0.132)$.

Five months after grafting, survival varied from $86.6 \%$ to $13.3 \%$ among the treatments evaluated, with significant differences after the Bonferroni correction $(p<0.0083)$ between treatments. The grafts with better results occurred in the materials with hybrid tree scions (Fig. 4). In the two treatments where the effect of the position of the scion in the crown of the hybrid donor trees was separately evaluated, the results were statistically the same. On the other hand, the successful sprouting of the graft achieved with hybrid scions taken from both positions of the crown, was statistically superior to the grafting performed in the two treatments in which pure species donor tree scions were used. Significant differences were not found $(p>0.0083)$ when the comparison was made just between grafts made with scions taken from the two crown positions of pure species donor trees (Fig. 4).

\section{Pearson's correlation test and stepwise regression to adjust the Logit and Weibull models}

A Pearson's correlation test indicated that there is highly significant collinearity only between the height of the rootstock and height of the graft, so it was decided to exclude the rootstock height variable in the adjustment of the Logit and Weibull models and include graft height, since the literature on Pinus grafts indicates that this last variable influences survival (González-Jiménez et al., 2017). However, the stepwise regression applied to select variables to adjust the Logit and Weibull models, indicated that none of the graft variables was useful to describe the probability 
379 of survival significantly and not affected the probability of graft mortality (Table 2), since the 380 only predictor variable that showed significant effect was the type of scion's donor tree.

381 Odds ratio for graft survival according to the Logit model

382 It was found in the Logit model that the intercept and the coefficient of the variable "type of 383 scion donor tree" were highly significant $(p \leq 0.0001)$ after the Bonferroni correction, in terms of 384 the mortality of Pinus engelmannii grafts (Table 3). The probability $p\left(x_{i}\right)$ of graft survival rates 385 for each type of scion donor tree, during the evaluation period, is illustrated in Figure 5.

386 The probability dispersion diagram (Fig. 5) indicates a different decreasing rate of the probability 387 of graft survival, between the analyzed hybrid trees and pure species trees trough time. In the 388 probability diagram, it is possible to verify that due to the positive value of the $\beta_{1}$ coefficient of the "type of scion donor tree" predictor variable (Table 3), the probability of survival increases

390

391

392

393

394

395

396

397

398

399

400

401

402

403

404

405

406

407

408

409

410

411

412

413

414

415

416

417 by increasing the predictor variable $x_{i}$ by one unit, that is to say when increasing from $x_{0}=0$ (pure species trees) to $x_{1}=1$ (hybrid trees). The probability of graft survival with pure-species tree scions $\left(p\left(x_{0}\right)\right)$ was $25 \%$, while the probability of graft survival with hybrid tree scions $\left(p\left(x_{1}\right)\right)$ was $83.3 \%$ at the end of the five-month evaluation period.

At the end of the evaluation, the number of live specimens were 50 grafts with scions from hybrid-donor trees and 15 grafts with scions from pure species-donor trees; meanwhile, there were 10 and 45 dead grafts with hybrid and pure species tree scions, respectively. The estimated odds ratio (Eq. 3) for the variable "type of scion donor tree" was 15.0, which was obtained with the following operation, which uses the relative frequencies of live and dead grafts by treatment: Odds ratio $=\frac{a x d}{b \times c}=\frac{(50 / 120) \times(45 / 120)}{(10 / 120) \times(15 / 120)}=15.0$

Note that because the numerator variable $a$ represents the relative frequency of living grafts with scions from hybrid-donor trees, the result of the equation means that the odds ratio (proportion) of successful grafts made with scions from hybrid-donor trees, in the long run after the evaluation period, will be 15 to one with respect to grafts made with pure species-donor tree scions.

\section{Survival probability of Pinus engelmannii grafts according to the AFT model and Weibull} risk function

The AFT model was highly significant for predicting the average survival time elapsed until the occurrence of the death event of one or more of the grafts that reached alive up until the end of the evaluation period. In addition, all parameters of the AFT model were highly significant even after the Bonferroni correction (Table 4).

According to the coefficient value $\delta$ of the "type of scion donor tree" variable, and when applying the exponent $\left(e^{(1.06)}=2.88\right)$, it is interpreted that when the $x$ variable takes the value of 1 (hybrid-donor trees), the survival time $T$ increases at a rate of 2.88 compared to what happens when $\mathrm{x}=0$ (pure species-donor trees). When developing the AFT model (Eq. 3), with the estimated parameters (Table 4) it was obtained that the estimated survival time for grafts with scions from pure species-donor trees is 156 days on average, while the graft survival time with scions from hybrid-donor trees is 450 days on average. In other words, it is estimated that the 
418 death of at least one graft would occur at 156 days in the case of pure-species tree scions and up

419 to 450 days among the grafts of hybrid tree scions.

420 Depending on the $T$ results mentioned above, the difference in survival between treatments will

421 increase as time $T$ also increases. The high statistical significance $(p \leq 0.0001)$ of the two

422 parameters ( $\alpha$ and $\sigma$ ) and the coefficient $\delta$ shown in Table 4 , allows accepting that the AFT

423 model is significant and therefore, its parameters can be used to estimate the risk function (Eq. 4)

424 and to estimate the hazard ratio (Eq. 8) of graft mortality, as a function of the type of scion donor

425 tree. The parameters obtained for the Weibull risk function $(h(t))$ are shown in Table 5.

426 When applying equation (9), the hazard ratio at a time $t=150$ days for the "type of scion donor

427 tree" variable was 0.14 when referring to hybrid trees, while the hazard ratio in relation to scions

428 donated by pure species trees is much higher (1.22). Whereby, the risk of graft death when using

429 hybrid-donor tree scions is reduced by $86 \%$ ((1.0 minus hazard ratio) $(100)=(1-0.14)(100)=$

430 86). This risk of death, depending on the "type of scion donor tree" variable, is represented in the

431 diagnostic diagram of the Weibull model (Fig. 6).

432 The cumulative risk of death of grafts with pure species-donor tree scions is greater during the

433 entire evaluation period compared to graft survival when using hybrid tree scions. The

434 cumulative risk of death of grafts with hybrid tree scions was only 0.14 at five months of

435 evaluation. The differences are notorious in the risk of death between treatments, since the

436 accumulated hazard ratio curves are not intercepted at any point in the diagram.

437 Discussion

438 In this side veneer grafting experiment a general survival of 54\% (including all treatments) was

439 obtained. Propagating Pinus and other coniferous species through grafting techniques has been

440 viable in several experiments, obtaining survival results that range between 50 and $80 \%$ (Lott et

441 al., 2003; Hibbert-Frey et al., 2011; Almqvist, 2013a). Interspecific grafting is an alternative to

442 improve propagation results by this means, in species that have been difficult to graft by

443 intraspecific methods (Barnes, 2008). In two of the four treatments evaluated in our research,

444 survival of at least $80 \%$ was obtained; the two treatments with this survival were those of grafts

445 made with scions from Pinus engelmannii x $P$. arizonica hybrids. In this study, the results are

446 similar to those obtained by Hibbert-Frey et al. (2011), who reported 86\% survival in Abies

447 fraseri (Pursh) Poir, in top cleft grafts at four months of evaluation. A similar success rate

448 (53.8\% at six months of evaluation) was obtained by González-Jiménez et al. (2017) in side-

449 veneer grafts of Pinus leiophylla Schiede ex Schltdl. et Cham. On the other hand, in a top cleft-

450 grafting experiment of Pinus sylvestris L., a 75\% survival was obtained in the first year after

451 grafting (Almqvist, 2013a). Also, Almqvist (2013b) reported a survival of $84.7 \%$ six months after

452 the grafting of $P$. sylvestris, using the top cleft-grafting technique. In side-veneer grafts of Pinus

453 engelmannii, a 22.5\% survival rate was reported at six months of grafting (Pérez-Luna et al.,

454 2019).

455 In the present experiment, significant differences were observed between the graft of pure

456 species-donor and hybrid-donor trees at five months of evaluation, with greater survival in the

457 grafts of scions taken from hybrid trees. In the final evaluation (five months) of our study, an 
$45883 \%$ survival was observed in grafts made with Pinus engelmannii $\mathrm{x}$ P. arizonica hybrid scions, 459 while in grafts with scions taken from pure species $P$. engelmannii, a survival was achieved of 460 only $25 \%$. However, research on the use of Pinus hybrids for graft propagation is scarce; in top 461 cleft grafts of Pinus palustris Mill. x P. elliottii Engelm. var. elliottii hybrids on P. palustris rootstocks, Lott et al. (2003) reported a $72 \%$ survival rate one year after grafting. Although there were no significant differences in the first four months of evaluation, we observed that the survival percentage was always higher in the treatments with scions from hybrid-donor trees (Fig. 3). This suggests that the scions taken from hybrid trees may have a greater potential for graft adaptation and healing, than the scions taken from pure species trees, when both are grafted on rootstock from pure species $P$. engelmannii. The importance of the study of forest areas that have experienced hybridization has be pointed out, especially in order to identify the advantages of using hybrids for adaptation to extreme environments in which pure species trees have less vigor, a solution that can be used in reforestation programs (Zobel \& Talbert, 1984; López-Upton et al., 2001; Wachowiak et al., 2016). Several studies also indicate that the vigor in plant species may be greater in hybrid offspring, at least in the first generation of hybridization (Djidonou et al., 2016; Xu et al., 2016; Zhang et al., 2019). Avila-Flores et al. (2016a) in their work on hybrid stands of trees in Durango, Mexico, in which the degree of hybridization between Pinus engelmannii $\times$ P. arizonica was studied, indicate that these hybrids may have the potential for adaptation in drought conditions.

478 Some authors consider that the presence of hybrids in seed stands decreases the genetic gain of the progeny (Arnold \& Hodges, 1995; Rieseberg \& Carney, 1998; Wehenkel et al., 2017). However, other authors recognize the importance of studying the effect of hybrids in breeding programs (López-Upton et al., 2001; Nunes et al., 2018). Mabaso, Ham \& Nel (2019) reported that the Pinus patula Schltdl. \& Cham. x P. tecunumanii F. Schwedtf. ex Eguiluz et J.P.Perry hybrids, showed little resistance to frost. However, Nunes et al. (2018) found better increments and adaptability of the hybrid $P$. elliottii var. elliottii $\mathrm{x} P$. caribaea var. hondurensis, when planted in regions suitable for the establishment of the pure species P. elliottii, in Brazil. In this sense, and according to our results, although there are no differences between the growth and vigor of the scions' donor trees, progeny tests should be performed to determine the hybrids' potential for establishing asexual seed orchards, for obtaining appropriate seeds for the production of plants in the nursery, which would serve for improving the establishment of commercial forest plantations in disturbed areas. On the other hand, it is advisable to carry out studies to determine the viability of the use of hybrids for vegetative propagation, provided there is evidence that hybrid trees show better adaptation and development characteristics than pure species-parent trees (López-Upton et al., 2001; Reig et al., 2019).

In this work, only the effect of the pure-species tree scions of Pinus engelmannii and hybrids of $P$. engelmannii $\mathrm{x} P$. arizonica, grafted onto pure species Pinus engelmannii rootstocks was evaluated, finding that the best combination was to graft hybrid scions onto pure species rootstocks. In a graft experiment by Larix gmelinii (Rupr.) Rupr. var. japonica, it was found that 
498

499

500

501

502

503

504

505

506

507

508

509

510

511

512

513

514

515

516

517

518

519

520

521

522

523

524

525

526

527

528

529

530

531

532

533

534

535

536

when using L. gmelinii var. japonica x L. kaempferi (Lamb.) Carr. hybrid rootstocks, survival was $92.6 \%$ in the first year of grafting, because the scions from pure species trees were very compatible with hybrid rootstocks (Kita et al., 2018). In our study, a similar percentage of survival (83.3\%) was found in grafts made with scions from Pinus engelmannii x P. arizonica hybrid trees on pure species Pinus engelmannii rootstocks (Fig. 4). Marchal et al. (2017) performed grafts on Larix decidua Mill. x L. kaempferi hybrid rootstocks using three types of scions: Hybrid scions from L. decidua x L. kaempferi, scions from the pure species L. decidua trees and scions from the pure species L. Kaempferi trees, and found that the grafts with purespecies tree scions from both species were the best. They concluded that the success in graft survival in the genus Larix was not favored by the use of scions from hybrid trees. This situation contrasts with the results found in the present study, where better survival was obtained in grafts made with hybrid tree scions.

In our study, we consider that a possible cause of the high mortality (and potential incompatibility) in the pure species grafts is a result of the high presence of resin channels in Pinus engelmannii trees. This conclusion was reached, based on the work of Pérez-Luna et al. (2019), who found that a greater number of resin channels in the pure species $P$. engelmannii scions corresponded to a diminished survival of side-veneer grafts. In addition, Yeaton, Yeaton \& Waggoner III (1983) indicate that trees with fewer stomata in the needles are more resistant to stress; and $P$. arizonica contains fewer stomata in the needles than P. engelmannii (GarcíaArévalo \& González-Elizondo, 2003), which could have affected the degree of compatibility in the graft between the $P$. engelmannii x $P$. arizonica hybrid scion and the pure species $P$. engelmannii rootstock.

In this work, no significant differences were found between the grafts with scions from the upper third of the crown compared to the middle third, neither in hybrid-donor trees nor in pure species-donor trees. In contrast, Holst, Stanton \& Yeatman (1963), found that the survival rate of Pinus sylvestris grafts was $96 \%$ when grafting scions from the top of the crown, while scion grafts from the bottom of the crown had a survival rate of $82 \%$. Also, in Abies fraseri top cleft grafts, a $90 \%$ survival rate with scions taken from the top of the crown was achieved; results that were statistically different $(p \leq 0.05)$ with respect to the survival rate achieved in grafts with scions from the bottom part of the crown, which ranged between $50 \%$ and $70 \%$ (Hibbert-Frey et al., 2011).

In our results, there were no significant differences between the different positions of the scions in the pure species tree crown $(p=0.73)$. However, a trend was observed for a greater survival in grafts with scions from the middle third of the crown, compared to the upper third (Fig. 4).

Further studies are necessary to verify the possible effect of the scions' position on the tree crown on the success of grafting in Pinus engelmannii and other species of the same genus.

Rosier et al. (2005) reported that the Abies fraseri scions from the lower zone of the crown were better for achieving the propagation of this species by rooting stem cuttings. Although grafts and cuttings are different vegetative propagation techniques, there are species like Pinus leiophylla

Peer) reviewing PDF | (2019:10:42481:1:1:NEW 11 Dec 2019) 
537 that have been propagated by both methods, and some of the factors that have influenced their

538

539

540

541

542

543

544

545

546

547

548

549

550

551

552

553

554

555

556

557

558

559

560

561

562

563

564

565

566

567

568

569

570

571

572

573

574

575

success are similar (Cuevas-Cruz, 2014; Cuevas-Cruz et al., 2015).

The graft variables of the scions and rootstocks showed no significant effects on the probability of graft death in this study, as the stepwise regression revealed that none of the graft variables significantly affected graft survival (Table 2). This may mean that the survival of grafts from pure species $P$. engelmannii and $P$. engelmannii $\mathrm{x} P$. arizonica hybrids is not affected by the diameter and length of the scions and rootstocks, nor by the height and diameter of the section where the graft is tied. On the other hand, significant differences were found only in relation to the type of scion donor tree (Table 1).

However, González-Jiménez et al. (2017) found that, in Pinus leiophylla side-veneer grafts, there was greater success when grafting at a height close to the base of the rootstock (5 to $10 \mathrm{~cm}$ ) with a 53\% survival rate. In another Pinus leiophylla grafting experiment, it was found that when the diameter of the rootstock was larger, the quality and development of the grafts were higher (González-Jiménez, 2017). In future studies, it will be important to use rootstocks and scions of different ages and sizes to conduct studies on the effect of the dasometric characteristics of the rootstocks and scions on the grafting success of $P$. engelmannii and other species of Pinus. Furthermore, satisfactory results were found in this study in the adjustment of the Logit model and the Weibull risk function to obtain the odds ratio and the hazard ratio respectively, which allowed estimating the graft survival and death probabilities depending on the "type of scion donor tree" variable. It should be noted that the use of survival models in research concerning commercial forest plantations or vegetative propagation of conifers has been very scarce (SigalaRodriguez et al., 2014). The only recent work found in this regard is that of Pérez-Luna et al. (2019), who reported that it was possible to estimate the hazard ratio for grafts with donor tree scions of different ages, with the adjustment of the Cox proportional hazards model.

Survival models were very useful for calculating the estimated average survival time of the grafts that remained alive until the end of the evaluation period. Furthermore, knowing the effect of the variables studied through the odds ratio and the hazard ratio will be very useful for decision making in subsequent research.

It is advisable to continue investigating the factors involved in the success or failure of graft propagation of Pinus species, at least those of greater economic or environmental importance, with a view to forming asexual and clonal seed orchards. The results obtained in this study can serve as a basis for future work in this area of research.

\section{Conclusions}

The sprouting of grafts on pure species Pinus engelmannii rootstocks was better when using scions from Pinus engelmannii $\mathrm{x}$ P. arizonica hybrid-donor trees. By contrast, using scions from the pure species trees increased the probability of death of grafts of this species. The lower survival rate in grafts made with pure-species trees scions was noticeable from the third month of grafting, which may indicate that mortality in grafts with scions of the pure species trees occurs earlier than the mortality of grafts with hybrid tree scions. 
576 The position of the scions in the crown of hybrid or pure species-donor trees did not show

577 significant effects on the evaluated treatments. As a result, the success rate may be similar when

578 grafting with scions collected from any part of the tree crown of the analyzed species.

579 Furthermore, the dimensions of the graft variables evaluated in the scions and grafted rootstocks

580 seemed not have influenced the probability of graft survival.

581 The adjustment of the Weibull accelerated failure time model made it possible to predict that

582 there is a greater probability of death when using scions of pure species Pinus engelmannii trees.

583 Adjustment of the Logit model also allowed for obtaining the odds ratio for survival, in response

584 to the aforementioned variable, observing that there is greater success in grafting when using

585 scions taken from hybrid $P$. engelmannii $\mathrm{x} P$. arizonica trees.

586 Acknowledgements

587 The authors are grateful to M.C. Santiago Solís González for the support provided in the

588 harvesting the vegetative material used in the present study. We also thank Dra. Socorro

589 González Elizondo for the support provided for the botanical identification of the studied

590 species.

591 References

592 Aedo S, Pavlov S, Clavero F. 2010. Riesgo relativo y Odds ratio ¿Qué son y cómo se

593 interpretan? Revista Obstetricia y Ginecología 5:51-54

594 Almqvist C. 2013a. Survival and strobili production in topgrafted scions from young Pinus

595 sylvestris seedlings. Scandinavian Journal of Forest Research 28:533-539 DOI:

$596 \quad 10.1080 / 02827581.2013 .803598$.

597

598

599

600

601

602

603

604

605

606

607

608

609

610

611

612

613

614

Almqvist C. 2013b. Interstock effects on topgraft vitality and strobili production after topgrafting in Pinus sylvestris. Canadian Journal of Forest Research 43:584-588 DOI: 10.1139/cjfr2012-0507.

Arnold ML, Hodges SA. 1995. Are natural hybrids fit or unfit relative to their parents? Trends in ecology \& evolution 10:67-71 DOI: 10.1016/S0169-5347(00)88979-X.

Ávila-Flores IJ, Hernández-Díaz JC, González-Elizondo MS, Prieto-Ruíz JA, Wehenkel C. 2016a. Degree of hybridization in seed stands of Pinus engelmannii Carr. in the Sierra Madre Occidental, Durango, México. PLoS ONE 11:e0152651 DOI: 10.1371/journal.pone.0152651.

Ávila-Flores IJ, Hernández-Díaz JC, González-Elizondo MS, Prieto-Ruíz JA, Wehenkel C. 2016b. Pinus engelmannii Carr. in nortwestern México: A review. Pakistan Journal of Botany 48:2159-2166

Barton AM, Swetnam TW, Baisan CH. 2001. Arizona pine (Pinus arizonica) stand dynamics: local and regional factors in a fire-prone madrean gallery forest of Southeast Arizona, USA. Landscape Ecology 16:351-369 DOI: 10.1023/A:1011189408651.

Barnes HW. 2008. Grafting of Cedrus atlantica onto Pinus strobus. Combined Proceedings International Plant Propagator's Society 58:334-335

Bland JM, Altman DG. 2000. The odds ratio. BMJ 320:1468 DOI: 10.1136/bmj.320.7247.1468. 
615 Carroll KJ. 2003. On the use and utility of the Weibull model in the analysis of survival data.

616

617

618

619

620

621

622

623

624

625

626

627

628

629

630

631

632

633

634

635

636

637

638

639

640

641

642

643

644

645

646

647

648

649

650

651

652

653

Control Clinical Trials 24:682-701 DOI: 10.1016/s0197-2456(03)00072-2.

Chaou CH, Chen HH, Chang SH, Tang P, Pan SL, Yen AMF, Chiu TF. 2017. Predicting length of stay among patients discharged from the emergency department using an accelerated failure time model. PloS one 12:e0165756 DOI: 10.1371/journal.pone.0165756.

Chidumayo EN, Gumbo DJ. 2013. The environmental impacts of charcoal production in tropical ecosystems of the world: A synthesis. Energy for Sustainable Development 17:86-94 DOI: doi.org/10.1016/j.esd.2012.07.004.

Cuevas-Cruz JC. 2014. Propagación vegetativa de Pinus leiophylla Schiede ex Schltdl. et Cham. M.S. Thesis, Colegio de Postgraduados.

Cuevas-Cruz JC, Jiménez-Casas M, Jasso-Mata J, Pérez-Rodríguez P, López-Upton J, VillegasMonter A. 2015. Asexual propagation of Pinus leiophylla Schiede ex Schltdl. et Cham. Revista Chapingo Serie Ciencias Forestales 21:81-95 DOI: 10.5154/r.rchscfa.2014.08.033.

Djidonou D, Simonne AH, Koch KE, Brecht JK, Zhao X. 2016. Nutritional quality of fieldgrown tomato fruit as affected by grafting with interspecific hybrid rootstocks.

HortScience 51:1618-1624 DOI: 10.21273/HORTSCI11275-16.

FAO-CONAFOR. 2009. Revisión del Programa Estratégico Forestal 2025 (PEF 2025) y del Programa Nacional Forestal 2001-2006 (PNF 2001-2006), en el marco del proyecto $\mathrm{UTF} / \mathrm{MEX} / 072$. Available at

http://www.conafor.gob.mx:8080/documentos/docs/4/4402Revision\%20del\%20PEF\%2020 25\%20y\%20PRONAFOR\%202001-2006.pdf (accessed 02 September 2019).

Fiedler CE, Arno SF, Keegan CE, Blatner KA. 2001. Overcoming America's wood deficit: an overlooked option. AIBS Bulletin 51:53-58 DOI: 10.1641/0006-

3568(2001)051[0053:OASWDA]2.0.CO;2.

Friedrich SC, Hernández-Díaz JC, Leinemann L, Prieto-Ruíz JÁ, Wehenkel C. 2018. Spatial genetic structure in seed stands of Pinus arizonica Engelm. and Pinus cooperi Blanco in the State of Durango, Mexico. Forest Science 64:191-202 DOI: 10.1093/forsci/fxx007.

García-Árevalo A, González-Elizondo MS. 2003. Pináceas de Durango. Xalapa, Veracruz, México: Instituto de Ecología, A.C.

George B, Seals S, Aban I. 2014. Survival analysis and regression models. Journal of Nuclear Cardiology 21:686-694 DOI: 10.1007/s12350-014-9908-2.

Ghorbani N, Yazdani-Charati J, Anvari K, Ghorbani N. 2016. Application of Weibull accelerated failure time model on the disease-free survival rate of breast cancer. Iranian Journal of Health Sciences 4:11-18 DOI: 10.18869/acadpub.jhs.4.2.11.

González-Jiménez B. 2017. Crecimiento y calidad del injerto en función del árbol donador en Pinus leiophylla. In: González TMA, Alanis RE, eds. XIII Congreso Mexicano de Recursos Forestales 2017. Linares, Nuevo León, México, 230.

González-Jiménez B, Jasso-Mata J, Jiménez-Casas M, Castillo-Martínez CR. 2017. Clonación por injerto de árboles maduros de Pinus leiophylla de un huerto semillero sexual. In:

PeerJ reviewing PDF | (2019:10:42481:1:1:NEW 11 Dec 2019) 
654

655

656

657

658

659

660

661

662

663

664

665

666

667

668

669

670

671

672

673

674

675

676

677

678

679

680

681

682

683

684

685

686

687

688

689

690

691

692

González TMA, Alanis RE, eds. XIII Congreso Mexicano de Recursos Forestales 2017. Linares, Nuevo León, México, 204.

Gray LK, Hamann A, John S, Rweyongeza D, Barnhardt L, Thomas BR. 2016. Climate change risk management in tree improvement programs: selection and movement of genotypes. Tree Genetics \& Genomes 12:23 DOI: 10.1007/s11295-016-0983-1.

Hare RC. 1984. Application method and timing of gibberellin $\mathrm{A}_{4 / 7}$ treatments for increasing pollen conebud production in southern pines. Canadian Journal of Forest Research. 14:128-131 DOI: 10.1139/x84-024.

Hastie T, Tibshirani R. 1987. Non-parametric logistic and proportional odds regression. Journal of the Royal Statistical Society: Series C (Applied Statistics) 36:260-276 DOI: $10.2307 / 2347785$.

Hibbert-Frey H, Frampton J, Blazich FA, Hundley D, Hinesley E. 2011. Grafting fraser fir (Abies fraseri): effect of scion origin (crown position and branch order). HortScience 46:91-94 DOI: 10.21273/HORTSCI.46.1.91.

Holst MJ, Stanton JA, Yeatman CW. 1963. Greenhouse grafting of spruce and hard pine at the Petawawa Forest Experiment Station, Chalk River, Ontario. In: Hatcher RJ, ed. Species index for technical notes. Ottawa: Government of Canada, Department of Forestry, 57-63.

Igl W. 2018. Calculation of hazard ratios of parametric survival model in R- A tutorial [Draft]. Available at http://wilmarigl.de/wpcontent/uploads/2018/01/tutorial_hr_parsurvmodels.pdf(accessed 25 September 2019).

Jayawickrama KJS, Jett JB, McKeand SE. Rootstock effects in grafted conifers: A review. 1991. New Forests 5:157-173 DOI: 10.1007/BF00029306.

Kita K, Kon H, Ishizuka W, Agathokleous E, Kuromaru M. 2018. Survival rate and shoot grafted Dahurian larch (Larix gmelinii var. japonica): a comparison between Japanese larch ( $L$. kaempferi) and $\mathrm{F}_{1}$ hybrid larch (L. gmelinii var. japonica x L. kaempferi) rootstocks. Silvae Genetica 67:111-116 DOI: 10.2478/sg-2018-0016.

Kleinbaum DG, Klein M. 2002. Logistic Regression. In: Dietz K, Gail M, Krickeberg K, Tsiatis A, Samet J, eds. Statistics for biology and health. New York: Springer-Verlag, 513.

López-Upton J, Velazco-Fiscal V, Jasso-Mata J, Ramírez-Herrera C, Vargas-Hernández JJ. 2001. Hibridación natural entre Pinus oocarpa y P. pringlei. Acta Botanica Mexicana 57:51-66

Lopez JL, Abt RC, Dvorak WS, Hodge GR, Phillips R. 2018. Tree breeding model to assess financial performance of pine hybrids and pure species: deterministic and stochastic approaches for South Africa. New Forests 49: 123-142 DOI: 10.1007/s1 1056-017-9609-1. Lott LH, Lott LM, Stine M, Kubisiak TL, Nelson CD. 2003. Top grafting longleaf $x$ slash pine $\mathrm{F}_{1}$ hybrids on mature longleaf and slash pine interstocks. In: Tree Improvement and Genetics $27^{\text {th }}$ Sothern Forest Tree Improvement Conference, Oklahoma: 96-101.

Luukkanen O, Johansson S. 1980. Effect of exogenous gibberellins on flowering in Pinus sylvestris grafts. Physiology Plant 50:365-370 DOI: 10.1111/j.1399-3054.1980.tb04114.x. 
693 Mabaso F, Ham H, Nel A. 2019. Frost tolerance of various Pinus pure species and hybrids.

694

695

696

697

698

699

700

701

702

703

704

705

706

707

708

709

710

711

712

713

714

715

716

717

718

719

720

721

722

723

724

725

726

727

728

729

730

731

Southern forests : a journal of forest science 81:273-280 DOI:

10.2989/20702620.2019.1615212.

Marchal A, Muñoz F, Millier F, Sánchez L, Pâques LE. 2017. Hybrid larch heterosis: for which traits and under which genetic control? Tree Genetics \& Genomes 13:92 DOI: 10.1007/s11295-017-1177-1.

Moore R. 1984. A model for graft compatibility-incompatibility in higher plants. American Journal of Botany 71:752-758 DOI: 10.1002/j.1537-2197.1984.tb14182.x.

Mudge K, Janick J, Scofield S, Goldschmidt EE. 2009. A history of grafting. Horticultural Reviews 35:437-493

Muñoz-Flores HJ, Coria-Avalos VM, García-Sánchez JJ, Velasco-Bautista E, Martínez-Molina G. 2012. Evaluación de una plantación de Pinus greggii Engelm. con dos espaciamientos. Revista Mexicana de Ciencias Forestales 3:57-70

Muñoz-Flores HJ, Prieto-Ruíz JÁ, Flores-García A, Pineda-Ojeda T, Morales-González E. 2013. Técnicas de injertado "enchapado lateral" y "fisura terminal" en Pinus pseudostrobus Lindl. México: Instituto Nacional de Investigaciones Forestales Agrícolas y Pecuarias (INIFAP).

Mutke S, Gordo J, Gil L. 2005. Cone yield characterization of a Stone Pine (Pinus pinea L.) clone bank. Silvae Genetica 54:4-5 DOI: 10.1515/sg-2005-0028.

Neale DB, Kremer A. 2011. Forest tree genomics: growing resources and applications. Nature Reviews Genetics 12:111-112 DOI: 10.1038/nrg2931.

Novo-Fernández A, Franks S, Wehenkel C, López-Serrano PM, López-Sánchez CA. 2018. Landsat time series analysis for temperate forests cover change detection in the Sierra Madre Occidental, Durango México. International Journal of Applied Earth Observation and Geoinformation 73:230-244 DOI: 10.1016/j.jag.2018.06.015.

Nunes S, Marum L, Farinha N, Pereira VT, Almeida T, Sousa D, Mano N, Figueiredo J, Dias MC, Santos C. 2018. Somatic embryogenesis of hybrid Pinus elliottii var. elliottii $\mathrm{x} P$. caribaea var. hondurensis and ploidy assessment of somatic plants. Plant cell tissue and organ culture (PCTOC) 132:71-84 DOI: 10.1007/s11240-017-1311-7.

Oliveira KF, Nogueira AC, Higa AR. 2018. Productivity of cones and sedes in a clonal orchard of Pinus taeda Linnaeus. Advances in Forestry Science 5:293-298

Opoku EM, Opuni-Frimpong E, Dompreh D. 2018. Developing sustainable regeneration techniques for four African mahogany species: grafting methods for success and growth. New Forests 50: 1-16 DOI: 10.1007/s11056-018-9677-x.

Pérez-Luna A, Prieto-Ruíz JÁ, López-Upton J, Carrillo-Parra A, Wehenkel C, Chávez-Simental JA, Hernández-Díaz JC. 2019. Some factors involved in the success of side veneer grafting of Pinus engelmannii Carr. Forests 10:112 DOI: 10.3390/f10020112.

Pijut PM. 2002. Eastern white pine flowering in response to spray application of gibberellin $\mathrm{A}_{4 / 7}$ or Procone ${ }^{\mathrm{TM}}$. Northern Journal of Applied Forestry 19:68-72 DOI: 10.1093/njaf/19.2.68.

Peer) reviewing PDF | (2019:10:42481:1:1:NEW 11 Dec 2019) 
732 Pina A, Errea P. 2005. A review of new advances in mechanism of graft compatibility-

733

734

735

736

737

738

739

740

741

742

743

744

745

746

747

748

749

750

751

752

753

754

755

756

757

758

759

760

761

762

763

764

765

766

767

768

769

770 incompatibility. Scientia Horticulturae 106:1-11 DOI: 10.1016/j.scienta.2005.04.003.

Pohar M, Stare J. 2006. Relative survival analysis in R. Computer Methods and Programs in Biomedicine 81:272-278 DOI: 10.1016/j.cmpb.2006.01.004.

Prieto-Ruíz JÁ, Cornejo-Oviedo EH, Domínguez-Calleros PA, Návar-Chaidez JDJ, MarmolejoMoncivais JG, Jiménez-Pérez J. 2004. Estrés hídrico de Pinus engelmannii Carr., producido en vivero. Forests Systems 13:443-451

Qi J. 2009. Comparison of proportional hazards and accelerated failure time models. M.S. Thesis, University of Saskatchewan.

Reig G, Salazar A, Zarrouk O, Forcada CF, Val J, Moreno MÁ. 2019. Long-term graft compatibility study of peach-almond hybrid and plum based rootstocks budded with European and Japanese plums. Scientia Horticulturae 243:392-400 DOI:

10.1016/j.scienta.2018.08.038.

Rieseberg LH, Carney SE. 1998. Plant hybridization. The new phytologist 140:599-624 DOI: 10.1046/j.1469-8137.1998.00315.x.

Rosales-Mata S, Prieto-Ruíz JÁ, García-Rodríguez JL, Madrid-Aispuro RE, Sigala-Rodríguez JÁ. 2015. Preacondicionamiento de Pinus engelmannii Carr. bajo diferentes condiciones ambientales en vivero. Revista Mexicana de Ciencias Forestales 6:64-71

Rosete-Vergés FA, Pérez-Damián JL, Villalobos-Delgado M, Navarro-Salas EN, Salinas-Chavéz E, Remond-Noa R. 2014. El Avance de la deforestación en México 1976-2007. Madera y Bosques 20:21-35

Rosier CL, Frampton J, Goldfarb B, Wise FC, Blazich FA. 2005. Stumping height, crown position, and age of parent tree influence rooting of stem cuttings of Fraser fir. HortScience 40:771-777 DOI: 10.21273/HORTSCI.40.3.771.

R Core Team. 2013.) $R$ : A language and environmental for statistical computing. Vienna: The $\mathrm{R}$ foundation for statistical computing. Available at http://www.R-project.org/ (accessed 15 march 2019)

SEMARNAT (Secretaría de Medio Ambiente y Recursos Naturales). 2016. Anuario estadístico de la producción forestal 2016. Available at

https://www.gob.mx/cms/uploads/attachment/file/282951/2016.pdf(accessed 02 September 2019).

Şevik H, Topaçoğlu O. 2015. Variation and inheritance pattern in cone and seed characteristics of Scots pine (Pinus sylvestris L.) for evaluation of genetic diversity. Journal of Environmental Biology 36:1125-1130

Sigala-Rodríguez JÁ, Sosa-Pérez G, Sarmiento-López H, Rosales-Mata S. 2014. Análisis de riesgos para la supervivencia de una reforestación con Pinus arizonica Engelm. en Chihuahua, México. Revista Forestal Baracoa 33:24-32

Skousen JG, Dallaire K, Scagline-Mellor S, Monteleone A, Wilson-Kokes L, Joyce J, Thomas C, Keene T, DeLong C, Cook T, Jacobs DF. 2018. Plantation performance of chestnut hybrids

PeerJ reviewing PDF | (2019:10:42481:1:1:NEW 11 Dec 2019) 
771

772

773

774

775

776

777

778

779

780

781

782

783

784

785

786

787

788

789

790

791

792

793

794

795

796

797

798

799

800

801

802

803

804

805

806

807

808

809

810

and progenitors on reclaimed Appalachian surface mines. New Forests 49:599-611 DOI: 10.1007/s1 1056-018-9643-7.

Staubach MC, Fins L. 1988. Grafting western larch. Western Journal of Applied Forestry 3:5556

Stewart JF, Will R, Crane BS, Nelson D. 2016. Occurrence of shortleaf x loblolly pine hybrids in shortleaf pine orchards: implications for ecosystem restoration. Forest Science 63:225-231 DOI: $10.5849 /$ forsci.15-167.

Sullivan LM, Massaro JM, D’Agostino Sr RB. 2004. Presentation of multivariate data for clinical use: The Framingham study risk score functions. Statistics in medicine 23:16311660 DOI: doi.org/10.1002/sim.1742.

Valdés AE, Centeno ML, Fernández B. 2003. Changes in the branching pattern of Pinus radiata derived from grafting are supported by variations in the hormonal content. Plant science 165:1397-1401 DOI: 10.1016/j.plantsci.2003.08.003.

Valera L, Garay V, Flores A, Sánchez J. 1999. Aparente incompatibilidad en injertos de Pinus caribaea var. hondurensis en el huerto semillero clonal, Santa Cruz de Bucaral, FalcónVenezuela. Revista Forestal Venezolana 43:25-31

van Houwelingen HC. 2000. Validation, calibration, revision and combination of prognostic survival models. Statistics in Medicine 19:3401-3415 DOI: 10.1002/10970258(20001230)19:24<3401::AID-SIM554>3.0.CO;2-2.

Vargas-Hernández JJ, Vargas-Abonce JI. 2016. Effect of giberellic acid $\left(\mathrm{GA}_{4 / 7}\right)$ and partial stem girdling on induction of reproductive structures in Pinus patula. Forest Systems 25:11

Vazquez AI, Gianola D, Bates D, Weigel KA, Heringstad B. 2009. Assessment of Poisson, logit and linear models for genetic analysis of clinical mastitis in Norwegian Red cows. Journal of Dairy Science 92:739-748 DOI: 10.3168/jds.2008-1325.

Wachowiak W, Żukowska WB, Wójkiewicz B, Cavers S, Litkowiec M. 2016. Hybridization in contact zone between temperature European pine species. Tree Genetics \& Genomes 12:48 DOI: $10.1007 / \mathrm{s} 11295-016-1007-x$.

Wehenkel C, Ramírez F, Simental-Rodríguez SL, Hernández-Velasco J, Reyes-Murillo CA, Salazar-Jiménez F, Domínguez-Amaya N, Bailón-Soto CE, Hernández-Díaz JC, CarrilloParra A. 2017. Las características de los híbridos en rodales semilleros de pino, Durango, México. In: González TMA, Alanis RE, eds. XIII Congreso Mexicano de Recursos Forestales 2017. Linares, Nuevo León, México, 219.

Weisstein, EW. 2004. Bonferroni correction. Available at http://mathworld.wolfram.com/BonferroniCorrection.html (accessed 03 December 2019).

Wheeler NC, Steiner KC, Schlarbaum SE, Neale DB. 2015. The evolution of forest genetics and tree improvement research in the United States. Journal of Forestry 113:500-510 DOI: 10.5849/jof.14-120.

Xu X, Ali Z, Song W, Ghori N, Shao H, Ding J. 2016. Alterations of DNA methylation in diverse grafted hybrid tomatoes (Solanum lycopersicum L.). Pakistan Journal of Agricultural Sciences 53:107-112

Peer] reviewing PDF | (2019:10:42481:1:1:NEW 11 Dec 2019) 
811 Yeaton RI, Yeaton RW, Waggoner III JP. 1983. Changes in morphological characteristics of 812 Pinus engelmannii over an elevation gradient in Durango, México. Madroño 30:168-175 813 Zhang Z. 2016. Parametric regression model for survival data: Weibull regression model as an 814 example. Annals of Translational Medicine 4:484 DOI: 10.21037/atm.2016.08.45.

815 Zhang J, Wang P, Tian H, Wang Y, Jiang H 2019. Using a new hybrid rootstock significantly

816 increases the grafted plan rate and watermelon yield. International Agrophysics 33:97-106 817 DOI: $10.31545 /$ intagr/104402.

818 Zobel B, Talbert J. 1984. Applied forest tree improvement. New York: John Wiley \& Sons. 


\section{Table 1 (on next page)}

Values of the analyzed variables in grafts with scions from pure-species trees of Pinus engelmannii and from $P$. engelmannii $\times$ P. arizonica hybrids, on $P$. engelmannii rootstocks. 
Table 1 Values of the analyzed variables in grafts with scions from pure-species trees of Pinus engelmannii and from $P$. engelmannii $x$. arizonica hybrids, on $P$. engelmannii rootstocks.

\begin{tabular}{|c|c|c|c|c|c|}
\hline Graft variable & Minimum & $\begin{array}{l}\text { Mean } \pm \\
\text { standard } \\
\text { deviation }\end{array}$ & Maximum & $\begin{array}{l}\text { Variation } \\
\text { coefficient }\end{array}$ & $\begin{array}{l}p \text { value } \\
\text { one-way } \\
\text { ANOVA }\end{array}$ \\
\hline Scion length (SL -cm) & 4.0 & $8.1 \pm 2.0$ & 15.0 & 0.25 & $<0.0001$ \\
\hline Scion diameter (SD-mm) & 8.0 & $13.5 \pm 2.4$ & 21.5 & 0.18 & $<0.0001$ \\
\hline Rootstock height (RH-cm) & 11.0 & $17.4 \pm 3.9$ & 30.0 & 0.22 & $<0.0001$ \\
\hline $\begin{array}{l}\text { Rootstock diameter at the root crown } \\
\text { (RD-mm) }\end{array}$ & 11.0 & $18.4 \pm 3.6$ & 27.5 & 0.19 & $<0.0001$ \\
\hline Graft height (GH-cm) & 3.0 & $7.7 \pm 2.4$ & 15.0 & 0.30 & $<0.0001$ \\
\hline $\begin{array}{l}\text { Rootstock diameter at graft height } \\
\text { (GD-mm) }\end{array}$ & 9.6 & $15.4 \pm 2.9$ & 24.1 & 0.18 & $<0.0001$ \\
\hline
\end{tabular}

1 


\section{Table 2 (on next page)}

Stepwise regression to select variables to adjust the Logit model and the Weibull accelerated failure time model.

Where: $\mathrm{AIC}=$ Akaike information criterion; TDT $=$ Type of scion donor tree; SPC $=$ Position of the scion in the donor tree crown; $\mathrm{SL}=$ Length of the scion; $\mathrm{SD}=$ Scion diameter; $\mathrm{RD}=$ Diameter of the rootstock at the root crown; $\mathrm{GH}=$ Graft height; $\mathrm{GD}=$ Rootstock diameter at graft height. 
2

Table 2 Stepwise regression to select variables to adjust the Logit model and the Weibull accelerated failure time model. Where: $\mathrm{AIC}=$ Akaike information criterion; TDT = Type of scion donor tree; SPC = Position of the scion in the donor tree crown; SL $=$ Length of the scion; $\mathrm{SD}=$ Scion diameter; $\mathrm{RD}=$ Diameter of the rootstock at the root crown; $\mathrm{GH}=\mathrm{Graft}$ height; $\mathrm{GD}=$ Rootstock diameter at graft height.

\begin{tabular}{ccc}
\hline Variables & Number of variables & AIC \\
\hline TDT, SPC, SL, SD, RD, GH, GD & 7 & 135.5 \\
TDT, SPC, SD, RD, GH, GD & 6 & 133.6 \\
TDT, SPC, SD, RD, GD & 5 & 132.4 \\
TDT, SPC, RD, GD & 4 & 131.1 \\
TDT, SPC, GD & 3 & 130.0 \\
TDT, GD & 2 & 129.2 \\
TDT & 1 & 129.0 \\
\hline
\end{tabular}




\section{Table 3 (on next page)}

Level of significance of the Logit model estimators with respect to death probability of grafts of pure-species trees Pinus engelmannii and the $P$. engelmannii $\times$ P. arizonica hybrids. 
Table 3 Level of significance of the Logit model estimators with respect to death probability of grafts of pure-species trees Pinus engelmannii and the $P$. engelmannii $\mathbf{x}$. arizonica hybrids.

\begin{tabular}{llll} 
Parameter & Estimator & $|\mathbf{z}|$ & $\boldsymbol{p}<|\mathbf{z}|$ \\
\hline Intercept $(\alpha)$ & -1.09 & 0.68 & $<\mathbf{0 . 0 0 0 1}$ \\
$\begin{array}{l}\text { Coefficient of the "type of scion donor tree" }\left(\beta_{1}\right) \\
\text { variable }\end{array}$ & 2.70 & 0.45 & $<\mathbf{0 . 0 0 0 1}$ \\
\hline
\end{tabular}


Table 4 (on next page)

Estimation of the Weibull accelerated failure time model parameters to predict the graft survival time. 
Table 4 Estimation of the Weibull accelerated failure time model parameters to predict the graft survival time.

\begin{tabular}{llll}
\hline Parameter & Estimator & $|\mathbf{z}|$ & $\boldsymbol{p}<|\mathbf{z}|$ \\
\hline Intercept $(\alpha)$ & 5.0456 & 61.92 & $<\mathbf{0 . 0 0 0 1}$ \\
$\begin{array}{l}\text { Coefficient of the "type of scion donor tree" }(\delta) \\
\text { variable }\end{array}$ & 1.0595 & 4.80 & $<\mathbf{0 . 0 0 0 1}$ \\
Scale $(\sigma)$ & 0.5460 & -4.96 & $<\mathbf{0 . 0 0 0 1}$ \\
\hline
\end{tabular}




\section{Table 5 (on next page)}

Estimation of Weibull risk function parameters, to assess the risk of death in pine grafts, according to the type of donor tree. 
Table 5 Estimation of Weibull risk function parameters, to assess the risk of death in pine grafts, according to the type of donor tree.

Parameter

Estimator

Form parameter $(\lambda)$

$9.69 \times 10^{-05}$

Scale parameter $(\gamma)$

1.83

Coefficient of the "type of scion donor tree" $(\beta)$ variable

$-1.94$

1 
Figure 1

Morphological characteristics of pure species of Pinus engelmannii and $P$. engelmannii $\mathrm{x}$ P. arizonica hybrid.

(A) pure-species tree; (B) hybrid tree; (C) cones of pure species; (D) cone of hybrid; (E) fascicles of pure species; (F) fascicles of hybrid. Photo credit: M. Socorro González Elizondo. 


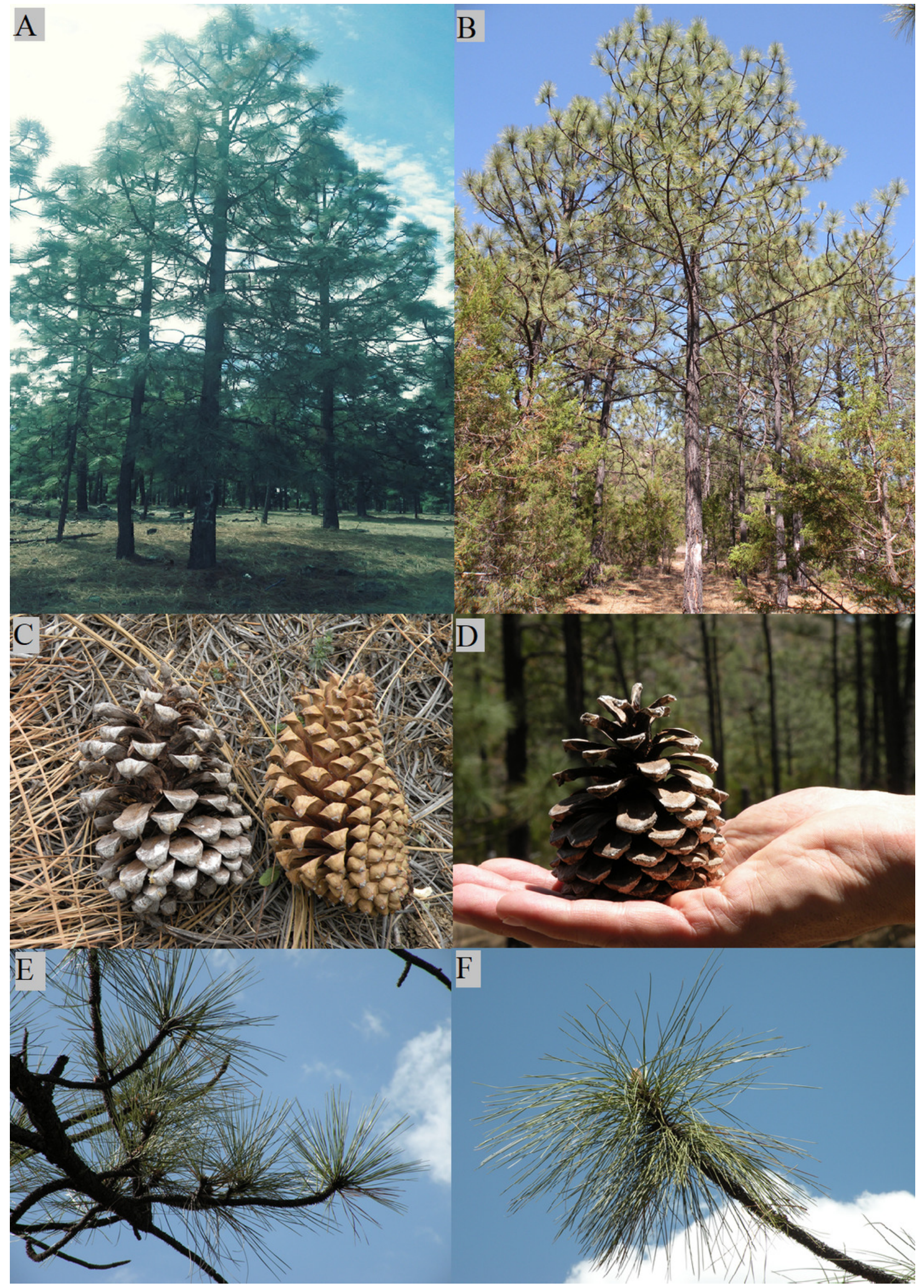


Figure 2

Measured sections to obtain the graft variables in side veneer grafts of Pinus.

(A) variables in rootstocks and grafts; (B) variables in scions. Photo credit: Alberto Pérez Luna.

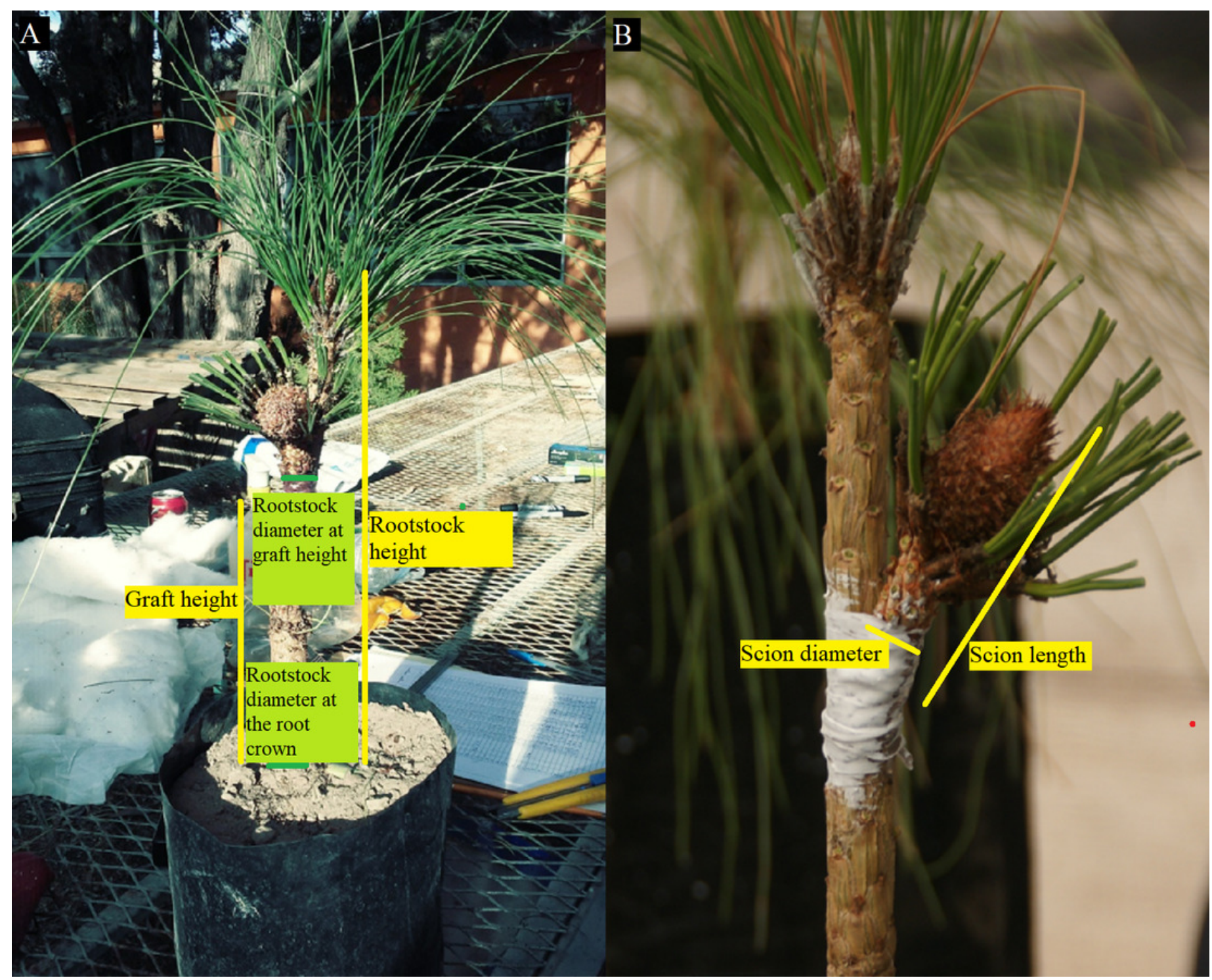




\section{Figure 3}

Monthly survival rate in grafts with scions from the pure species Pinus engelmannii and from the $P$. engelmannii $\times P$. arizonica hybrid for each treatment, in the first four months of evaluation.

Where: SUPTC $=$ Scion grafts from the upper third of the pure-species tree crown; SMPTC $=$ Scion grafts from the middle third of the pure-species tree crown; SUHTC = Scion grafts from the upper third of the hybrid tree crown; SMHTC = Scion grafts from the middle third of the hybrid tree crown. No significant differences were found between treatments in any separate month of evaluation. The whiskers represent the standard error of each treatment.

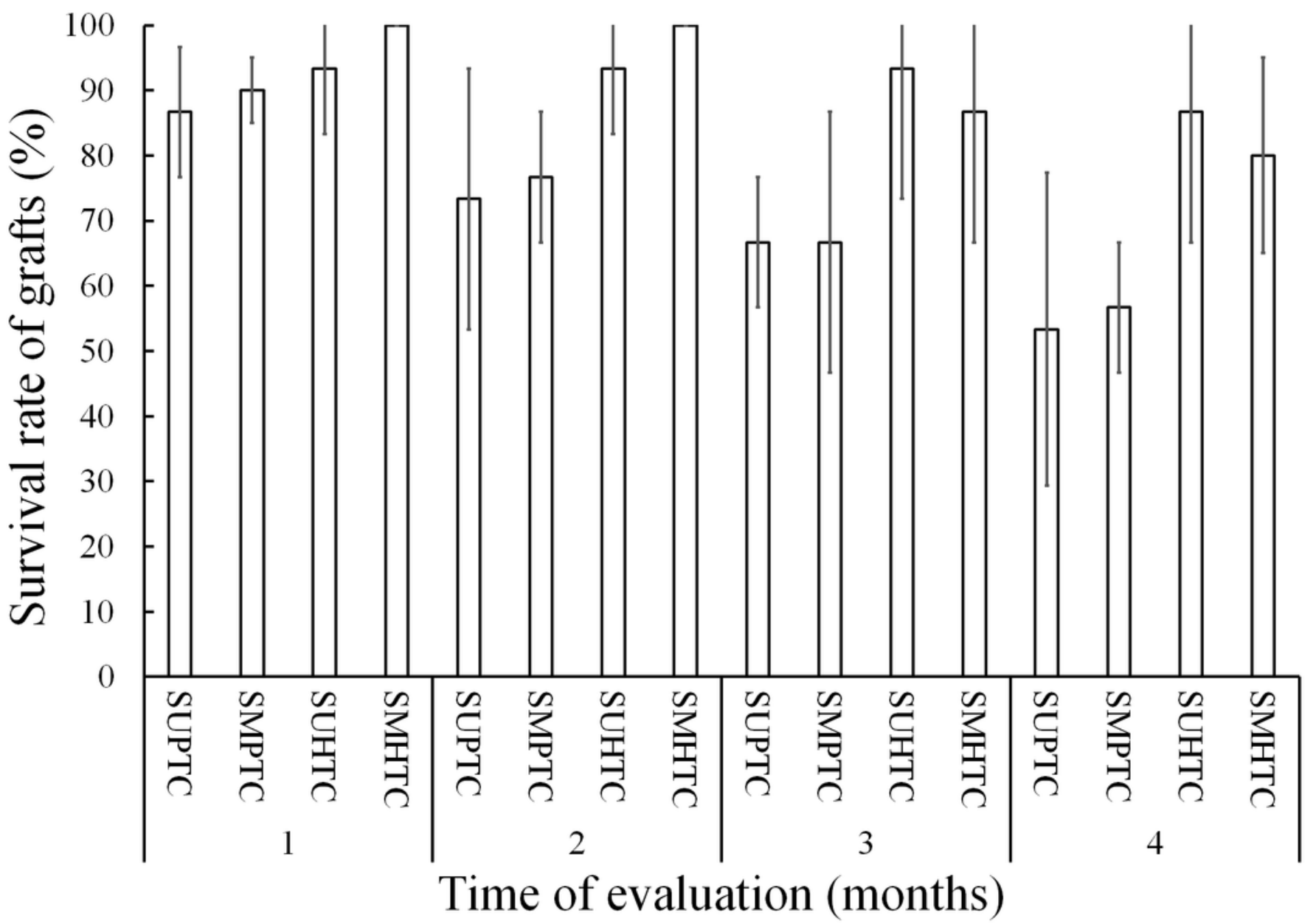




\section{Figure 4}

Monthly survival rate in grafts with scions from the pure species Pinus engelmannii and from the $P$. engelmannii $\times P$. arizonica hybrid for each treatment, in the fifth month of evaluation.

Where: SUPTC $=$ Scion grafts from the upper third of the pure-species tree crown; SMPTC $=$ Scion grafts from the middle third of the pure-species tree crown; SUHTC = Scion grafts from the upper third of the hybrid tree crown; SMHTC = Scion grafts from the middle third of the hybrid tree crown. Different letters indicate significant differences between treatments $(p \leq$ 0.0083). The whiskers represent the standard error of each treatment.

a

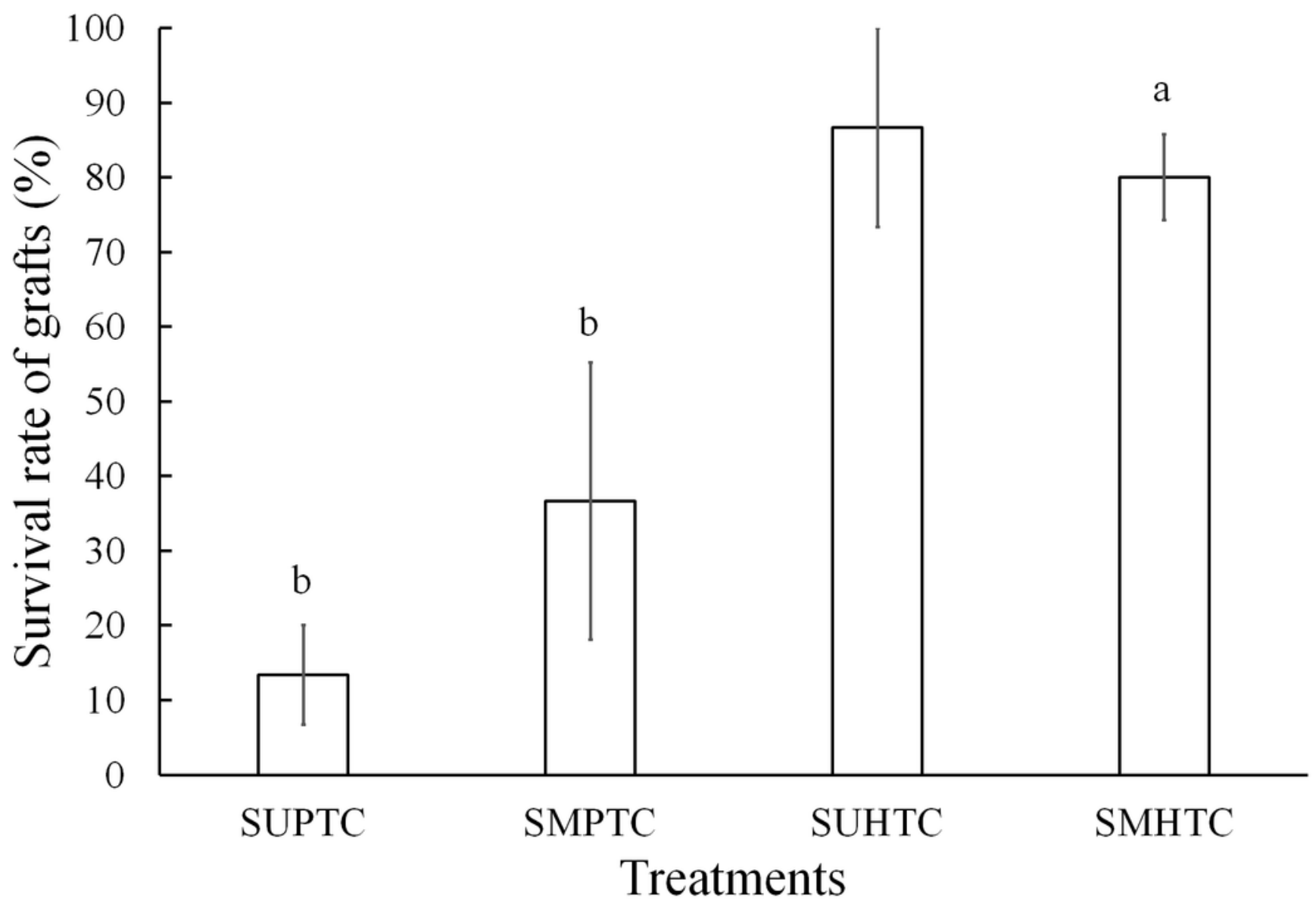


Figure 5

Graft survival probability diagram (in logarithmic basis) with scions from pure-species trees of Pinus engelmannii and from $P$. engelmannii $\times P$. arizonica hybrids.

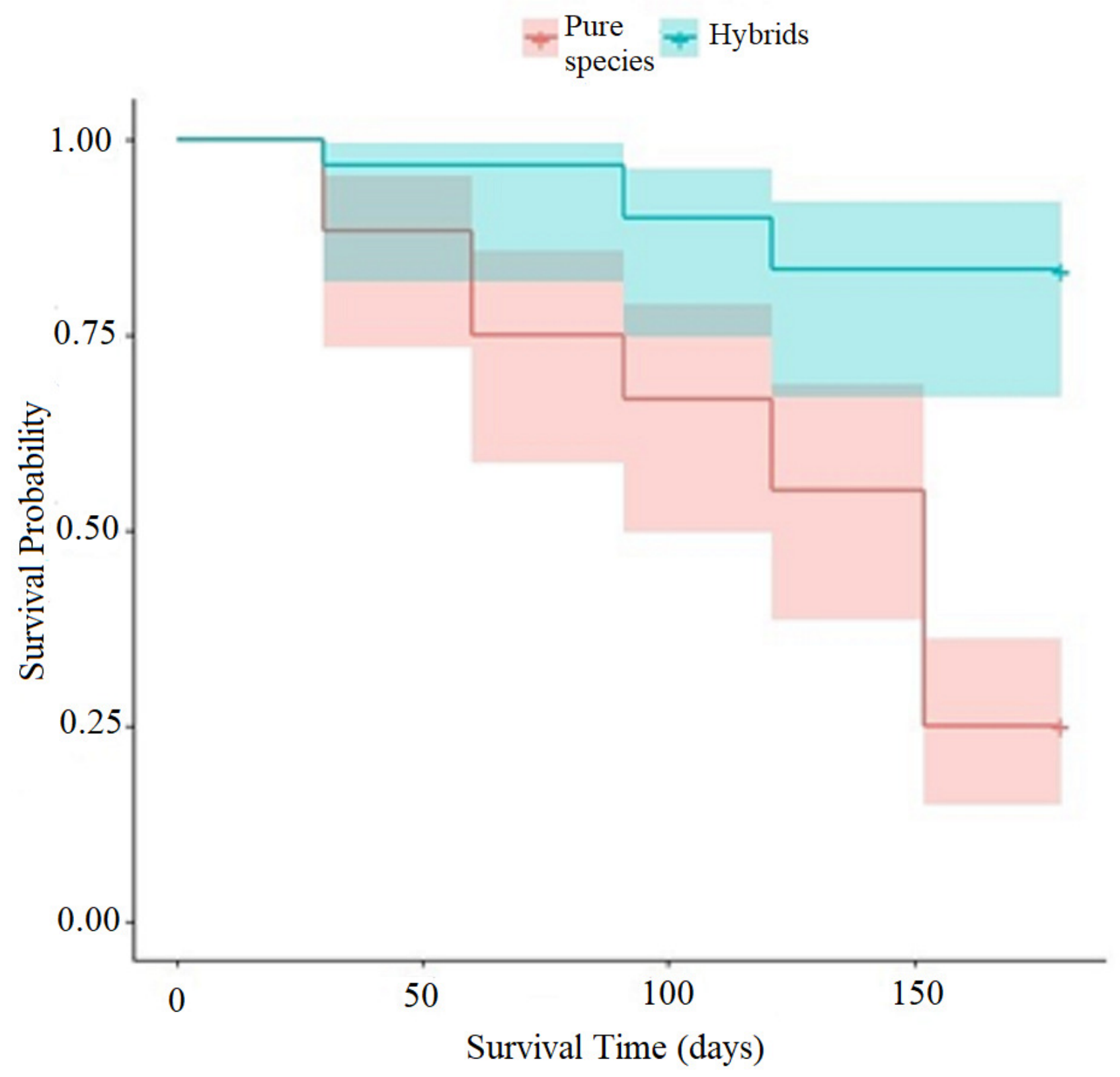


Figure 6

Diagnosis diagram of the accumulated hazard ratio in the five month evaluation time, according to the Weibull regression.

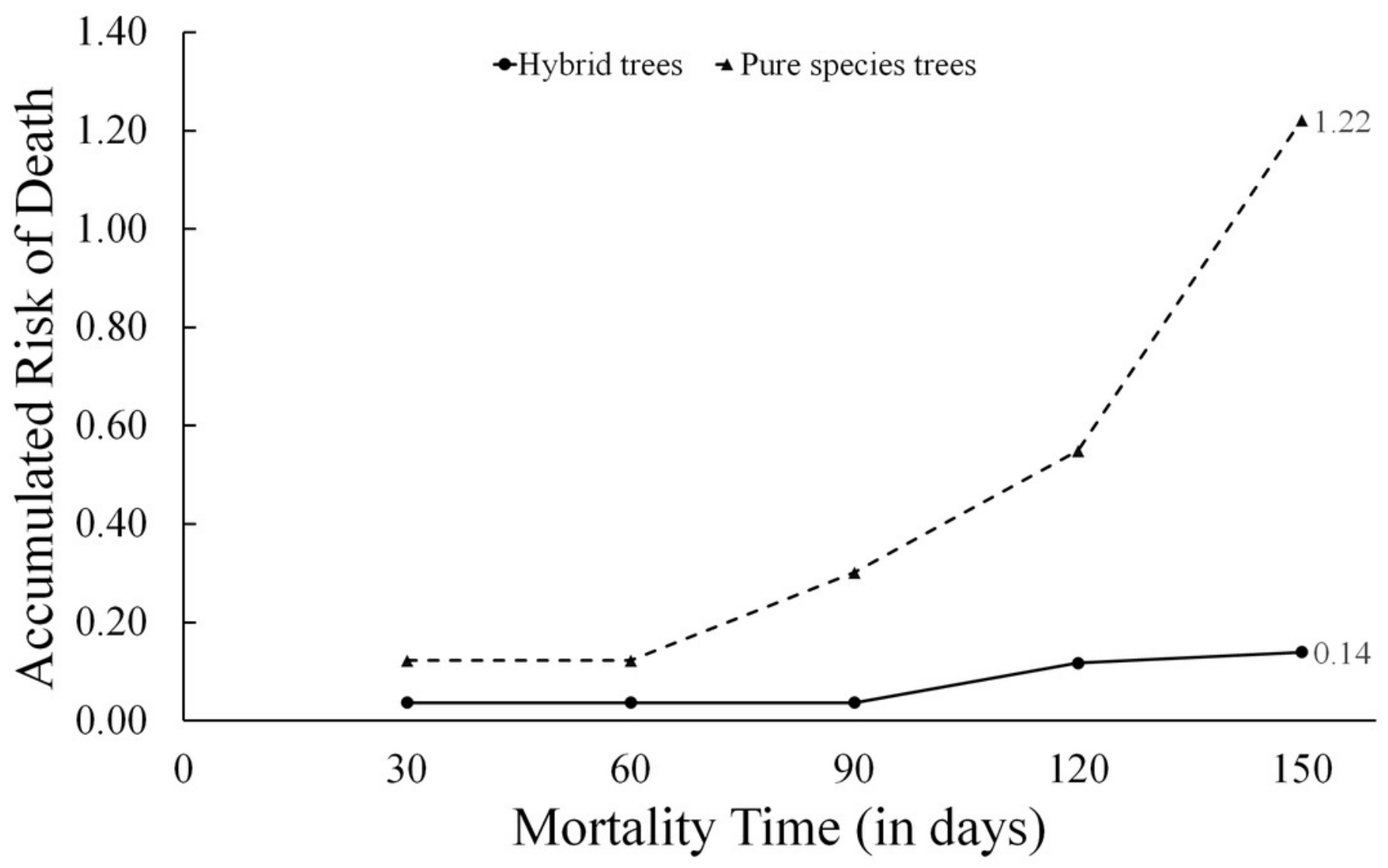

